\title{
TRANSPORT INFRASTRUCTURE QUALITY AND LOGISTICS PERFORMANCE IN EXPORTS
}

\author{
Cynthia Sénquiz-Díaz ${ }^{1}$ \\ date of paper receipt: \\ date of sending to review: \\ date of review receipt: \\ 26.02.2021. \\ 01.03.2021. \\ 18.03.2021. \\ Original Article \\ doi: 10.2478/eoik-2021-0008 \\ UDK 656.11:625.711.1] :330.342.2 \\ ${ }^{1}$ Universidad Ana G. Méndez, Business, Tourism and Entrepreneurship Division, PO Box 3030, Gurabo, Puerto Rico, \\ e- mail: cynthia.senquiz@gmail.com
}

\begin{abstract}
The quality of transport infrastructure and the efficiency of logistics services enhance economic development. This study measures the effects of transport-freight common modals and logistics performance on the exports of goods in 29 developing economies based on micro fixed-effects panel data for the period 2012-2018. The endogenous model proved a positive relationship with countries' outward orientation, highlighting the importance of transport infrastructure and logistics resources. The results revealed that the quality of roads and ports contribute significantly to higher exports in developing economies. However, the quality of airport infrastructure and logistics show a harmful effect. Notably, the logistics services level is a detrimental factor impacting the export of goods in developing economies. These results may adversely impact the potential contributions of other transport assets based on intermodal transport functionality and global market participation. Therefore, governments should prioritize formulating innovative policies and integration strategies with the private sector to improve the performance of logistics providers and fully utilize current transportation assets, particularly airports. These plans will facilitate higher exports, yield better development, and improve economic competitiveness while expanding export product diversification opportunities.
\end{abstract}

\section{Keywords:}

Developing Economies, Logistics, Transportation Infrastructure Quality, Exports of Goods, Economic Development 


\section{INTRODUCTION}

Development focuses on improving social, political, and economic conditions (Rodrigue \& Notteboom, 2017) that are notably important at the country level. Researchers like Solow (1956) and Romer (1994) had devoted theoretical and empirical frameworks to analyzing economic conditions in the pursuit of growth. For lesser advanced economies, identifying the factors that influence progress is of their utmost concern to becoming more industrialized and improving living standards. Its importance has been supported by unified efforts from different organizations, such as the World Bank (WB) and Aid for Trade support programs. These attempts allowed developing economies to increase their participation in global production networks by specializing in specific processes (Amendolagine, Presbitero, Rabellotti, \& Sanfilippo, 2019). Currently, increasing exports in developing economies has been recognized as one of the agendas of the Sustainable Development Goals for 2030.

Export-led growth is essential for economic development. While there are several perspectives on its impact, the neoclassical theory suggests that export performance contributes to expanding efficiency because it helps achieve greater economies of scale and supports resource utilization (Ram, 1987). These opportunities represent a valuable chance to strengthen the country's position in international markets. A major advantage of international trade is that it is a key strategy for raising living standards by creating employment and providing additional consumption options for citizens. However, accomplishing these goals demand a shift in stakeholders' perspectives, especially in countries with limited resources. These possibilities could be threatened by core resources, such as the quality of transportation infrastructure and logistics services, hurting the efficiency of the movement of export goods beyond borders while diminishing economic opportunities.

Transport remains a key development factor in any country. Inadequate transport infrastructure affects productivity, promoting weak market integration and impacting export levels (GarciaEscribano, Goes, \& Karpowicz, 2015). The significance of transportation infrastructure to economies is well-established in the literature. It leads to increased productivity, reallocation of labor, and capital (Bruinsma, Nijkamp, \& Rietveld, 1989), supports the reorganization of global production networks, and facilitates coping with diverse markets (Hummels, 2007). Accordingly, transportation and its interlinked multi-modal systems are essential when measuring a country or region's connectivity, while playing a fundamental role in accelerating growth (Carter, Chadda, \& Schonfeld, 1984). In these realms, logistics has been recently acknowledged as an essential resource for attaining growth and supporting an increased number of exports. The general perspective is that logistics services promote countries' participation in global market competitiveness (Arvis, Mustra, Panzer, Ojala, \& Naula, 2007; Arvis, Mustra, Ojala, Shepherd, \& Saslavsky, 2010) when they have a good level of efficiency.

It is well-known that developing countries face transport connectivity challenges (Organisation and Economic Co-Operation for Development, 2018). Such is the case for some African countries where these deficiencies impact opportunities for economic growth, industrialization, and development (OECD, 2018). Likewise, countries in Asia also encounter difficulties with roads and railways despite existent corridors. In contrast, Latin American developing countries have concerns with port facilities and high logistics costs (OECD, 2018). Besides affecting the productivity of local and foreign firms, these constraints may also interfere with the sustainable goals targeted for these economies. Despite these challenges, only a few studies have focused on measuring the effects of transport quality and logistics resources as an infrastructure of services facilitating a developing country's exports from a business perspective. For instance, a more substantial consideration of the private logistics sector as an essential development component may represent valuable benefits for 
these countries when considering financial constraints. Many current measures lead to the best use of infrastructure resources, whereas including the logistics sector in the facilitation of trade reforms demand the development of their services for the improvement of export capacity (Nordås, 2010). The inclusion of the logistics private sector into the transportation domain matters more than ever for developing economies where a gap still exists, compared to more advanced countries (Arvis, Ojala, Wiederer, Shepherd, Raj, \& Kiiski, 2018) with an increasing divergence pattern as shown in Fig. 1.

Figure 1. Comparison of logistics performance between 29 developing and 31 developed countries (Logistics Performance Index (LPI) figures are the countries' simple averages grouped according to the development classification. Developed economies included were Australia, Austria, Belgium, Bulgaria, Canada, Denmark, Estonia, Finland, France, Germany, Greece, Hungary, Ireland, Italy, Japan, Latvia, Lithuania, Luxembourg, Netherlands, New Zealand, Norway, Poland, Portugal, Romania, Slovak Republic, Slovenia, Spain, Sweden, Switzerland, United Kingdom, and United States).

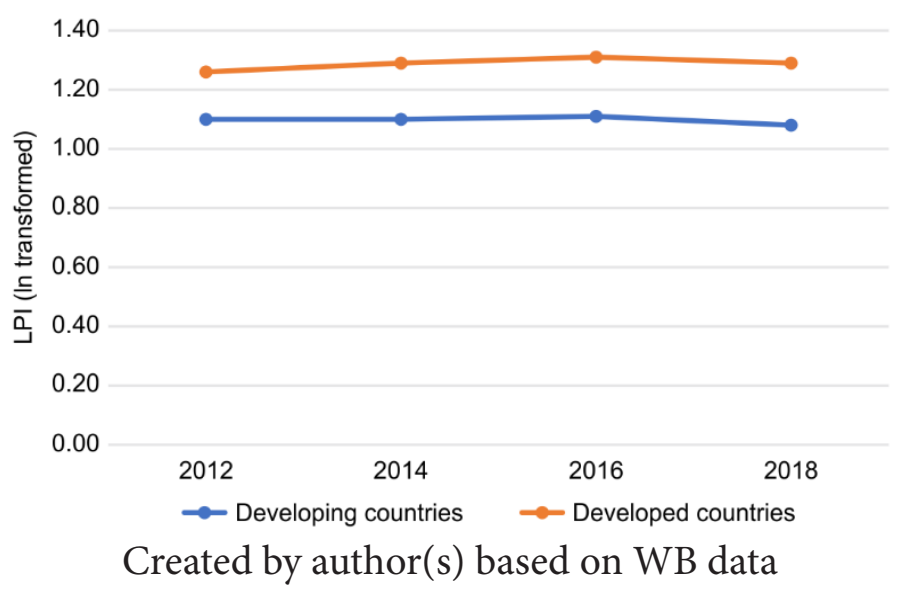

To this end, nations facing transportation infrastructure challenges and their full impact on the trade chain and level of competitiveness (Hoekman \& Nicita, 2010) are reflected, for example, on changes in transport modes. This is the reason why the assessment on common modes of transport infrastructure and logistics is necessary. Hence, the purpose of this study is to measure the effects of the quality of transport infrastructure and logistics in the export of goods in 29 developing countries using a balanced micro panel data for 2012-2018. The potential contribution of this research is three-fold. First, it supports operational efficiency and the strategic decisions of business leaders in different countries. Second, it allows managers to identify potential territories for business before allocating resources. Third, it helps governments better understand the essential requirements from a managerial perspective. Therefore, innovative, and more collaborative plans could be incorporated, improving the standard of living within the context of the infrastructure of services.

\section{THEORETICAL FRAMEWORK}

\subsection{EXPORTS OF GOODS}

Exports are goods and services produced by one country and sold to another. The number of exports represents globalization demands and countries' participation in different markets (Hesse, 2008). Studies have underscored export relevance as a core component for a country's development. For example, Were (2015) found that trade was significant in developing economies through a crosscountry study. Likewise, Upreti (2015) evidenced the positive effects of exports on the economic growth of less advanced countries. However, based on the export-led development hypothesis, Subasat (2002) found that the exports of middle-income economies had a weak correlation with 
economic growth, while those of low- and high-income economies experienced a reduced effect. Despite these results, the author warned about the importance of exports to all economies regardless of the income level. Previous works emphasized the relevance of export diversification. Hesse (2008) believed developing countries should diversify exports to become more prosperous. The author established the nonlinear effect of exports with developing economies. Similar findings were previously revealed by Levin and Raut (1997), where the manufactured exports-to-gross domestic product (GDP) ratio positively impacted economic growth. Further, Gabriele (2006) indicated that resource allocation for exports in developing economies should be part of a maximization strategy to avoid weak domestic economic integration. The author asserted that the merchandise composition of exports from less advanced economies affects the growth of these countries. In general, these studies seem to agree on the role of exports in boosting economic growth as previously established in the literature (Balassa, 1978; Giles \& Williams, 2000; Jung \& Marshall, 1985).

\subsection{TRANSPORTATION INFRASTRUCTURE MODAL SYSTEMS}

The quality of transportation infrastructure is an essential component in international competitiveness (Lakshmanan, 2007; OECD, 2013) that mostly depends on the government for provision and maintenance. It is expected to promote enhanced development in countries based on networking effects (Melo, Graham, \& Brage-Ardao, 2013) and the efficiency of the intermodal system.

Transportation plays a crucial role in the flow of goods, which can be affected by low quality infrastructure, reducing the country's opportunities to integrate into the world economy (Button \& Yuan, 2013; Hoekman \& Nicita, 2010). A well-developed infrastructure minimizes these adverse effects between regions It provides better locations for economic activities, lower transportation costs (Schwab, 2018; Cho, 2014), and complements production factors of labor and capital (Bruinsma et al., 1989). These arguments concur with that of Portugal-Pérez and Wilson (2010), who confirmed the positive impact of the quality of transportation infrastructure on growing exports in 101 countries, including developing economies. Rehman, Noman, and Ding (2020) recently found that infrastructure (including road, rails, and airports) benefits South Asian economies by increasing total exports and reducing trade deficit, while supporting regional economic relations.

\subsubsection{QUALITY OF ROADS}

Freights are brought to seaports and airports through inland freight modes (Rodrigue \& Notteboom, 2017), whose quality is relevant for timely deliveries, especially for sensitive goods. Beyond the socio-economic requirements of a country, roads have turned into a critical mode of transport especially for countries highly dependent on trade agreements, as is the case in Mexico. Other regions like Central America are also vulnerable to hauling shipments to ports and borders for additional regional trade (Carballo, Schaur, \& Volpe, 2017). Low quality roads may represent additional transportation costs, such as higher fuel consumption and transit time (Celbis, Nijkamp, \& Poot, 2014).

Previous investigations established the usefulness of road infrastructure in trade. For example, Cosar and Demir (2014) discovered that investments in Turkey's roads led to an increase in its exports and a reduction in its transportation costs, particularly for moving goods from the point of origin to ports and airports on time. Kodongo and Ojah (2016) established that growth in SubSaharan Africa was influenced by continuous spending in road infrastructure and increments in 
its accessibility. The authors learned that less developed economies have a broader benefit than developed ones, implying the endogenous effect of growth in infrastructure assets.

\subsubsection{QUALITY OF AIRPORTS}

Airport infrastructure in developing economies differ from that of advanced countries (Button, 2008). While developing countries have a good number of airports, they face constraints, such as poor quality, limited commercial services, and inadequate workforce. According to the WB, these factors affect the process of exporting time-sensitive products and intermediate inputs exchanged within production networks.

The contributions of air transportation infrastructure in the trade of goods have grown (Button, Doh, \& Yuan, 2010). Previous research confirmed its relation to economic development, explicitly considering airport extensions to different economic stimuli (Button et al., 2010), such as timely delivery and shifts in production networks. However, research analyzing its effect on developing economies seems scarce. A study from Florida, Mellander, and Holgersson (2015) evidenced the regional effects of airports in local development for U.S. metros. By controlling the impact of population size, industry structures, and human capital, they found that airports had a positive effect on regional development, which was mainly driven by the movement of people and cargo. The extensiveness of airports became more relevant as they increased in size. More actions could be performed through the airport facility, which according to Fink (2002), is ideal for reducing transit costs in landlocked economies.

\subsubsection{QUALITY OF PORTS}

According to the United Nations Conference on Trade and Development (UNCTAD) (2018), approximately $80 \%$ of global trade is transported via maritime ports; therefore, the quality and efficiency of ports are essential for the development of a country. Containerization is at the forefront of the globalization of markets, with its different connections and options for transshipments (Rodrigue \& Notteboom, 2017). After the containerization revolution of the mid-1960s, ocean shipping (UNCTAD, 2006) and specialized ships (Rodrigue \& Notteboom, 2017) provided transportation to far-reaching destinations (Fink, 2002). Maritime transport is considered a key component in international trade (Suárez-Alemán, Morales, Serebrisky, \& Trujillo, 2015), and is typically used for high volumes and restricted commodities that (1) cannot be shipped via air, or (2) have lower values.

Munim and Schramm (2018) evidenced the positive effects of port infrastructure in developing economies. A study analyzing 91 countries in 2010, 2012, and 2014 concluded that the quality of ports positively mediates logistics and seaborne trade. The study concluded that port quality is a differential component in developing and developed countries that positively influences trade in the former. Previously, Suárez-Alemán et al. (2015) evidenced how the efficiency of ports positively influenced developing regions markedly by connectivity levels. However, a real constraint of port facilities is the lack of space, causing congestion while increasing transport costs (Celbis et al., 2014).

\subsubsection{QUALITY OF RAILROADS}

Railroads are considered an efficient mode of inland transport, mostly for heavy freights over considerable distances. Railways particularly allow more benefits through economies of scale 
(Rodrigue \& Notteboom, 2017), such as smoother access to inputs, raw materials, and intermediate goods required by producers (Aritua, 2019).

The current literature reveals different findings on railway infrastructure. Based on a comparison between different transport assets, research findings from Arbués, Baños, and Mayor (2015) pointed out the positive impact of roads over railroads, airports, and ports in Spain's economic provinces. Their study demonstrated how infrastructure projects are beneficial to a country's location and the neighboring regions, resulting in spillovers that impact its economy. In contrast, the static spatial study of the belt and road initiative (BRI) of Wang, Lim, Zhang, Zhao, and Lee (2020) evidenced different effects per region in China where roads contributed the most positive effects to neighboring countries compared to railways. Furthermore, Donaldson (2018) learned that railroads in India decreased trade costs and pricing and increased interregional and regional trade. Recently, Aritua (2019) expanded railways to reduce environmental issues while sustaining the operational challenges of this transport mode.

\subsubsection{LOGISTICS PERFORMANCE}

The increases in global production networks and competition underline the strategic function of logistics performance in improving competitiveness (Arvis et al., 2007; Korinek \& Sourdin, 2011; Kunaka, Mustra, \& Saez, 2013). It allows countries to perform better in globalized markets, a critical aspect for developing countries in harnessing economic benefits (Arvis et al. 2007). Logistics performance is associated with proven service opportunities for increasing exports as a result of production networks. Therefore, its importance is becoming more relevant as facilitating trade and transport are commonalities for integrated markets (Arvis et al., 2010) and firms' engagement in modern production processes (Capineri, Leinbach, \& Gips, 2006). Logistics at a national level facilitates distributions from the origin to the final destination, becoming a core component of the GDP of industrialized countries (Korinek \& Sourdin, 2011).

Behar, Manners, and Nelson (2013) ascertained the value and contribution of logistics in reducing distance and trade costs. Hausman, Lee, and Subramanian (2013) highlighted the influence of logistics on decision-making in business, specifically on trade exchanges. Martí, Puertas, and García (2014a) found that countries that improve their logistics performance also experienced increased trade. Wang and Choi (2018) confirmed that logistics performance benefits exports in developing economies, especially when improving customs clearance and infrastructure in these countries. Previously, Martí, Puertas, and García (2014b) evidenced the significance of logistics performance when dealing with complex goods. Hence, these studies highlight the positive effects of logistics on the development of a country.

\section{METHODS}

The research employs balanced panel data for 29 countries covering 2012, 2014, 2016, and 2018. Countries were grouped at a priori according to their development stage based on the classifications of the World Economic Situation and Prospects (WESP) issued by United Nations - Department of Economic and Social Affairs. The WESP represents a joint assessment with the United Nations that analyzes development challenges, which can otherwise disrupt economic activities and damage long-term advancements (WESP, 2019). The WESP follows the WB assignation and reclassification of these countries according to their per capita gross national income (GNI). In this way, economies at lower- and middle-income levels are classified as developing economies. 
The countries were selected based on two main criteria. First, the data for the selected variables must be available for all countries and years. It is noteworthy that the logistics regressor corresponds to a biennial issue by the WB initiated in the year 2007 with a reduced number of countries. Hence, this is a cross-section data with a short period $(2<\mathrm{T}<4)$. Second, the country must hold the same development classification for the research period to avoid any wrong estimations due to changes in development stages. Table 1 shows the list of sample countries.

Table 1. List of developing countries

\begin{abstract}
Algeria, Argentina, Brazil, Cameroon, Chile, China, Colombia, Costa Rica, Egypt, Ghana, Hong Kong SAR, India, Indonesia, Jordan, Republic of Korea, Malaysia, Mexico, Nigeria, Pakistan, Panama, Peru, Philippines, Saudi Arabia, Senegal, South Africa, Thailand, Turkey, Uruguay, Vietnam
\end{abstract}

The study employs six variables on which the exports-to-GDP ratio depends. The ratio of exportsto-GDP is based on Munemo, Bandyopadhyay, and Basistha (2006). The economic trade system's basics concur to transactions for any flows between markets (Rodrigue \& Notteboom, 2017) depending on the country's openness and size, usually measured in economic literature as exports and imports of goods and services to GDP ratio (Kuznets, 1959). Hence, trade patterns could be affected by its size regardless of the trade policies (Tahir \& Azid, 2015). Economies depend on the exchange of goods for (1) development and life improvement, and (2) sales of domestic products (Hausman et al., 2013). Therefore, this research focuses on the contributions of exports to the economic development of these countries by considering the exports of goods-to-GDP ratio.

Following Portugal-Pérez and Wilson (2010), transportation infrastructure indicators correspond to the quality of standard modal freight transport and the extension of asset indexes (e.g., roads, ports, railroads, and airports), as derived from the Global Competitiveness Report (GCR) issued by the World Economic Forum (WEF). The Logistics Performance Index (LPI) represents assessments of freight-related operators provided by the WB, which aim to identify challenges and opportunities in the global logistics environment. Therefore, these indicators represent the views of world business leaders on the usual challenges they identify in their businesses. Appendix 1 defines the variables and sources employed as part of the data collection process.

Table 2. shows the descriptive statistics of the variables of the study. The low standard deviations suggest that variables are closer to the mean values, where the exports-to-GDP ratio has the highest variation at $66 \%$.

Table 2. Descriptive statistics of the variables

\begin{tabular}{lcccc}
\hline Variables & Minimum & Maximum & Mean & $\begin{array}{c}\text { Standard } \\
\text { Deviation }\end{array}$ \\
\hline LnRdsQ $_{i t}$ & 0.9162 & 1.8405 & 1.3405 & 0.2820 \\
LnAptsQ $_{i t}$ & 1.0986 & 1.9021 & 1.5412 & 0.2098 \\
LnPrtsQ $_{i t}$ & 0.8754 & 1.8718 & 1.4129 & 0.2464 \\
LnRalsQ $_{i t}$ & 0.2623 & 1.8563 & 0.9570 & 0.4006 \\
LnLogisP $_{i t}$ & 0.8816 & 1.4162 & 1.1018 & 0.1330 \\
LnExGDP $_{i t}$ & -2.3187 & 0.6295 & -1.3400 & 0.6606 \\
\hline
\end{tabular}

Source: Calculated by author(s)

Table 3. presents the bivariate correlation between variables, evidencing a statistical significance at the $1 \%$ level of exports-to-GDP ratio, except for ports and railroads. These were significant at the $5 \%$ level. 
Table 3. Bivariate correlation of variables

\begin{tabular}{|c|c|c|c|c|c|c|}
\hline & 1 & 2 & 3 & 4 & 5 & 6 \\
\hline 1. $\operatorname{LnRds} Q_{i t}$ & 1.00 & & & & & \\
\hline 2. LnAptsQ ${ }_{i t}$ & $0.78^{\star * \star}$ & 1.00 & & & & \\
\hline 3. $\operatorname{LnPrts} Q_{i t}$ & $0.83^{* * *}$ & $0.84^{* * *}$ & 1.00 & & & \\
\hline 4. LnRalsQ ${ }_{i t}$ & $0.70^{* * *}$ & $0.54^{\star * *}$ & $0.57^{* * *}$ & 1.00 & & \\
\hline 5. LnLogis $\mathrm{P}_{i t}$ & $0.70^{\star * *}$ & $0.67^{* * *}$ & $0.60^{* * *}$ & $0.65^{\star * *}$ & 1.00 & \\
\hline 6. LnExGDP ${ }_{i t}$ & $0.57^{\star * *}$ & $0.50^{* * *}$ & $0.46^{\star *}$ & $0.46^{* *}$ & $0.52^{\star \star \star}$ & 1.00 \\
\hline
\end{tabular}

${ }^{* * *} 1 \%$ significance level; ${ }^{* * 5 \%}$ significance level

a Correlations were assessed at two-tailed significance levels for $\mathrm{n}=116$ and accounted for the average for the whole period 2012-2018.

Source: Calculated by author(s)

\subsection{ESTIMATION METHODOLOGY}

Because country-based studies require different estimations to uncover the proper model, several tests were performed to choose the appropriate methodology. Initially, an ordinary least squares (OLS) estimation was performed, given by Equation 1:

$$
\hat{Y}_{i}=a+B X_{i}+\varepsilon_{i},
$$

where $\hat{Y}$ is the predicted value for the dependent variable (LnExGDP), $X$ is the regressor variable, $\varepsilon$ is the predicted error, $\mathrm{i}$ is the development classification, and $a$ and $B$ are the regression parameters coefficients.

Several specificity tests were performed. The Shapiro-Wilk test was conducted to determine the normality of the data. It is adequate for small sample sizes (Shapiro \& Wilk, 1965) and has proven its power on normality tests (Razali \& Wah, 2011). The normality assumption of the data could be observed when the p-value is $>0.05$ (Shapiro \& Wilk, 1965). The Ramsey's Regression Equation Specification Error Test (RESET) will confirm omitted variables from the regression equation. Lastly, the White test will examine whether the regression model's variance is constant, lending results for homoscedasticity presence.

Table 4 summarizes the null (H0) and alternative hypotheses (H1) for the above tests. The results in Table 5 support the failure to reject the null hypotheses on all performed tests. Besides, it was found that there are no multicollinearity (values $<10$ ) issues, although the variables were correlated, as evidenced in Table 6.

Table 4. Ordinary least squares specificity tests

\begin{tabular}{lll}
\hline Test & Assumption & Supported \\
\hline \multirow{2}{*}{ Shapiro-Wilk } & H0: Data are normally distributed. & p-value $>0.05$ \\
& H1: Data are not normally distributed. & p-value $<0.05$ \\
\hline \multirow{2}{*}{ Ramsey's RESET } & H0: No omitted nonlinearity. & p-value $>0.05$ \\
& H1: Omitted nonlinearity. & p-value $<0.05$ \\
\hline \multirow{2}{*}{ White } & H0: Homoscedasticity is present. & p-value $>0.05$ \\
& H1: Heteroscedasticity is present. & p-value $<0.05$ \\
\hline
\end{tabular}

Source: Calculated by author(s) 
Table 5. Interpretation of ordinary least squares specificity test

\begin{tabular}{lll}
\hline Test & Result & Decision \\
\hline Shapiro-Wilk & $0.9639, \mathrm{p}$-value $=0.00327312$ & Not supported $(\mathrm{p}$-value $<0.05)$ \\
\hline $\begin{array}{l}\text { Ramsey's } \\
\text { RESET }\end{array}$ & $\mathrm{P}(\mathrm{F}(2,108)>9.4574)=0.000164$ & Not supported $(\mathrm{p}$-value $<0.05)$ \\
\hline White & $\begin{array}{l}\mathrm{P}(\text { Chi-square }(20)>42.281173)= \\
0.002541\end{array}$ & Not supported $(\mathrm{p}$-value $<0.05)$ \\
\hline
\end{tabular}

Source: Calculated by author(s)

Table 6. Variance inflation factor values

\begin{tabular}{ll}
\hline Regressor & VIF \\
\hline LnRdsQ $_{i t}$ & 4.402 \\
\hline LnAptsQ $_{i t}$ & 4.554 \\
\hline LnPrtsQ $_{i t}$ & 4.187 \\
\hline LnRalsQ $_{i t}$ & 2.926 \\
\hline LnLogisP $_{i t}$ & 3.285 \\
\hline
\end{tabular}

Source: Calculated by author(s)

Findings from preliminary data estimations evidenced issues of heteroscedasticity and omitted variables. Therefore, static model panels, namely pooled ordinary least squares (POLS), randomeffects (RE) model, and fixed-effects (FE) model, were utilized. These models imply different specifications based on country-specific effects where several estimations are required to uncover the proper technique. First, the poolability test provided the best estimation methods between the POLS, RE model, and FE model. The Breusch-Pagan and Hausman tests were then employed to support the decision choice between the three above-mentioned models. Table 7 presents the results.

Table 7. Model specification results

Pooled OLS, using 116 observations

Included 29 cross-sectional units

Time-series length $=4$

Dependent variable: LnExGDP $_{\text {it }}$

Breusch-Pagan LM

$\mathrm{LM}=131.646, \mathrm{p}$-value $=1.78831 \mathrm{e}-030$
Hausman test

$\mathrm{H}=9.41961, \mathrm{p}$-value $=0.093453$

Source: Calculated by author(s)

The Breusch-Pagan LM supports the rejection of the POLS model at the $1 \%$ statistical significance level $(\mathrm{LM}=131.646, \mathrm{p}=1.78831 \mathrm{e}-030)$, suggesting the use of the RE model. However, the Hausman test led to the rejection of the RE model at a $10 \%$ statistical significance level $(\mathrm{H}=9.41961, \mathrm{p}=$ 0.0934), suggesting the use of the FE model. Since the model suffers from heteroscedasticity, a robust standard error (HAC) FE model was performed. Due to the short research period, a oneway FE panel model was chosen (Baltagi, 2016). 
An FE panel data regression model was employed to examine the effect of the chosen variables on the exports-to-GDP ratio based on Equation 2:

$$
\begin{gathered}
\operatorname{LnExGDP}_{i t}=\mathrm{a}_{i}+X_{i t} * \beta+\varepsilon_{i t} \\
i=1 \ldots \mathrm{N}, t=1 \ldots \mathrm{T}
\end{gathered}
$$

where $X$ represents the independent variables, subscript $i$ comprises the cross-sectional dimensional (country), $t$ denotes the time dimension (year), a denotes the unknown intercept for each country, $\beta$ represents the coefficients of each independent variable, and $\varepsilon$ is the error term.

\section{RESULTS}

Column 1 of Table 8 presents the results for the FE robust model. The Fischer test suggested a weaker model $[\mathrm{F}(5,28)=2.0839, \mathrm{p}=0.0972]$ where $\operatorname{lnLogis} \mathrm{P}_{i t}$ was the only variable statistically significant at the $10 \%$ level $(\beta=-0.7379, \mathrm{p}=0.0615)$, but negative. The R-squared obtained was 0.1314 (13.14\%). The Durbin-Watson test evidenced the presence of autocorrelation [1.27065, p-value $=5.08073 \mathrm{e}-005]$. Therefore, a lagged dependent variable (LDV) was used in the empirical analysis to (1) provide robust estimates of the effects of the independent variables (Wilkins, 2018) and (2) control for omitting factors, such as an export surge. To decide on the dependent variable's appropriate lag structure, correlations were visualized between the outcome variable (namely LnExGDP ${ }_{i t}$ ) and itself for different lagging periods. As shown in Fig. 2 the right structure corresponds to period 1 .

Figure 2. Correlations: LDV periods

a

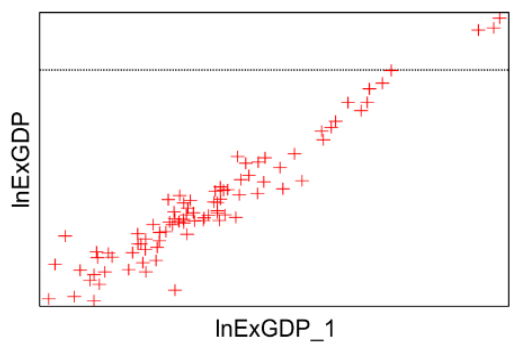

b

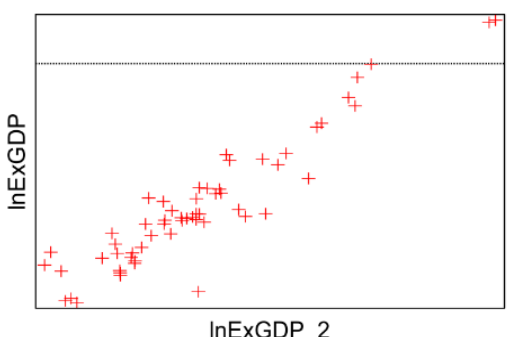

InExGDP 2

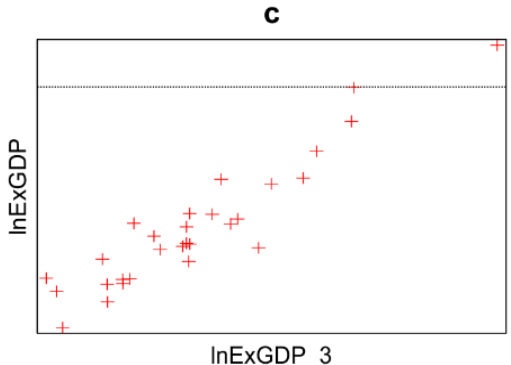

Source: Calculated by author(s)

The dynamic model is given by Equation 3:

$$
\begin{gathered}
\operatorname{LnExGDP}_{i t}=a_{i}+\mathrm{X}_{i t} * \beta+Y_{t-1} * \beta+\varepsilon_{i t} \\
i=1 \ldots \mathrm{N}, t=1 \ldots \mathrm{T},
\end{gathered}
$$

where $Y$ represents the dependent variable ( $\operatorname{LnExGDP})$, and ${ }_{t-1}$ indicates lagging for one period.

The results of the dynamic model (column 2) evidenced a better suitable model for developing countries $[\mathrm{F}(6,28)=18.5898, \mathrm{p}=1.36036 \mathrm{e}-008]$, where $\ln R \mathrm{~d} s \mathrm{Q}_{i t}$ and $\ln \operatorname{Prts}_{i t}$ confirmed a statistically significant and positive coefficient at the $10 \%$ level. However, $\ln \mathrm{Apts}_{i t}$ showed a statistically significant but negative coefficient at a $10 \%$ level. Additionally, lnLogis $\mathrm{P}_{i t}$ kept the negative coefficient $(\mathrm{B}=-0.8468)$, increasing its statistical 
significance to a $1 \%$ level. This result proves the impact of logistics even when controlling for past export value. The lagged dependent variable $\left(\operatorname{lnExGDP}{ }_{t-1}\right)$ is statistically significant at the 5\% level. The R-squared obtained was .3038 (30.38\%), whereas the Durbin-Watson test evidenced the absence of autocorrelation in the model [2.3634, $\mathrm{p}$-value $=0.99387$ ].

Table 8. Results of estimation techniques

\begin{tabular}{|c|c|c|}
\hline \multicolumn{3}{|c|}{ Dependent variable: LnExGDP $_{i t}$} \\
\hline & (1) & (2) \\
\hline Regressors & FE (HAC) & Dynamic \\
\hline \multirow[t]{2}{*}{ Constant } & $-1.9413^{\star \star}$ & -1.334 \\
\hline & $(0.7650)$ & $(0.8675)$ \\
\hline \multirow{2}{*}{$\operatorname{LnRds}_{i t}$} & 0.3286 & $0.5971^{\star}$ \\
\hline & $(0.4241)$ & $(0.3368)$ \\
\hline \multirow[t]{2}{*}{ LnAptsQ ${ }^{i t}$} & 0.4323 & $-1.0256^{*}$ \\
\hline & $(0.3602)$ & $(0.5049)$ \\
\hline \multirow[t]{2}{*}{$\operatorname{LnPrts}_{i t}$} & 0.2384 & $1.2391^{\star}$ \\
\hline & $(0.7043)$ & $(0.7064)$ \\
\hline \multirow{2}{*}{$\operatorname{LnRalsQ}_{i t}$} & -0.1512 & 0.0575 \\
\hline & $(0.2211)$ & $(0.1536)$ \\
\hline \multirow{2}{*}{$\operatorname{LnLogis}_{i t}$} & $-0.7379^{*}$ & $-0.8468^{\star * *}$ \\
\hline & $(0.3788)$ & $(0.2935)$ \\
\hline \multirow[t]{2}{*}{$\operatorname{LnExGDP}_{t-1}$} & & $0.2333^{* *}$ \\
\hline & & $(0.1036)$ \\
\hline \multicolumn{3}{|l|}{ Diagnostic tests } \\
\hline $\mathrm{n}$ & 29 & 29 \\
\hline Observations & 116 & 87 \\
\hline R-squared & 0.1314 & 0.3038 \\
\hline \multirow[t]{2}{*}{ F-test } & $2.08^{\star}$ & $18.5898^{* * *}$ \\
\hline & {$[0.0972]$} & [1.36e-008] \\
\hline Durbin-Watson & 1.2706 & 2.3634 \\
\hline
\end{tabular}

${ }^{\star * *} 1 \%$ significance level; ${ }^{* \star} 5 \%$ significance level; ${ }^{\star} 10 \%$ significance level a standard errors are shown in parentheses

$\mathrm{b}$ p-values are shown in square brackets

Source: Calculated by author(s)

\section{DISCUSSION}

Previous studies and organizations documented the importance of exports on the development of economies. While there is no conclusion about the exclusiveness of components of exports contributing to economic development, transportation infrastructure is one of the most relevant as it facilitates the movement of goods beyond borders.

This study examined the effects of transportation infrastructure quality, its most common freight modals, and logistics performance on the exports of developing countries. After applying different specification tests and regressions, the dynamic model with one period LDV was concluded to be the most appropriate. The endogenous model generated a positive relationship with the country's outward orientation to markets, supporting the value of transport and logistics resources for these countries. The findings indicated that the quality of ports and roads contribute to more exports. The quality of airports showed a negative effect with the detrimental factor and services of the logistics 
sector. As most of these countries depend on sensitive and low weight and volume products, the quality of logistics services and airport transport infrastructure might jeopardize global market participation. These results may adversely impact the potential contributions of other transport assets based on intermodal transport functionality. Therefore, improved policies and integration strategies should be prioritized by governments to increase the performance and competitiveness of private logistics providers, while improving the wellness of citizens. 


\section{CONCLUSION AND IMPLICATIONS}

This research extends the current literature on transport by focusing on the effects of the quality of infrastructure instead of the quantity on developing countries' economic development, providing important implications for governments and managers. The findings present a more detailed analysis especially on the integration of transport infrastructure for better business opportunities. The research also provides governments with a better picture of the importance of increasing collaboration between different stakeholders. Government management demands the inclusion of private agents, represented by the logistics providers on their networks. Since some of these countries face financial challenges, governments should prioritize logistics reforms to increase trade opportunities at a much lower cost and in much less time than investing in transport infrastructure quality.

The study also contributes to academia by extending current research about transportation infrastructure and logistics in developing countries. Current investigations mostly analyze transportation infrastructure based on quantity rather than quality, which is the principal criterion in this study. Moreover, research analyzing the effects of common modals of transport seems scarce, especially in airport infrastructures. Besides, the inclusion of the logistics sector and its influence on exports provide avenues for future research, such as identifying particular logistics components requiring specific advancement and innovative strategies. This research also integrates different academic fields such as economics, engineering, and international business, stressing the requirement for a more multidisciplinary approach in education at post-secondary institutions, allowing for a closer look at the actual operational requirements of a business.

The pursuit of better resource management based on multiple demands should promote a more tailored integration between governments and business leaders. More importantly, improved transport infrastructure and logistics services can enhance efficiency, facilitating a more sustained development. Therefore, integrating these resources acknowledges the requirement to positively adapt an infrastructure of services to properly address current and future development challenges.

\section{Limitations of the study}

This study's primary limitation is that it was subjected to the current information available, particularly with the logistics component, as any analysis based on secondary data. As more years of data become available, a longitudinal analysis is recommended. Moreover, the study only considers the number of export goods. Future analyses should consider classification of commodities for a more industrialized approach. While the study grouped the sample countries according to their development stage, it is not easy to estimate the precise costs and benefits. Such an assessment requires a case-by-case analysis and consideration to other country-specific factors.

Lastly, this study's results and discussions are based on different estimation techniques without stressing on their economic growth impact. However, as the most relevant variables relate to productivity, there is no reason to think these components would not positively impact economies, given the additional years for such consideration.

\section{Acknowledgments}

The author states no funding was involved. Also, the author is grateful and deeply appreciates the insights and helpful suggestions by Dr. César R. Sobrino Rodríguez, Professor of Economics at Universidad Ana G. Méndez, Business, Tourism \& Entrepreneurship Division, concerning the exports-to-GDP ratio employed in this research. 
Appendix 1. Definitions of variables and data sources.

\begin{tabular}{|c|c|c|}
\hline Variable & Measurements & Sources \\
\hline $\begin{array}{l}\text { Dependent } \\
\text { variable } \\
\text { LnExGDP }_{i t}\end{array}$ & $\begin{array}{l}\text { Goods provided to world-to-GDP } \\
\text { ratio (in US current dollars) ln } \\
\text { transformed values }\end{array}$ & WB \\
\hline $\begin{array}{l}\text { Independent } \\
\text { variables } \\
\text { LnRdsQ }_{i t}\end{array}$ & $\begin{array}{l}\text { Quality (condition and extensiveness) } \\
\text { of roads on a scale from } 1 \text { (worst in } \\
\text { the world) to } 7 \text { (among the best in the } \\
\text { world), ln transformed values }\end{array}$ & WEF \\
\hline $\operatorname{LnApts}_{i t}$ & $\begin{array}{l}\text { Quality (condition and extensiveness) } \\
\text { of airports on a scale from } 1 \text { (worst in } \\
\text { the world) to } 7 \text { (among the best in the } \\
\text { world), ln transformed values }\end{array}$ & WEF \\
\hline $\operatorname{LnPrts}_{i t}$ & $\begin{array}{l}\text { Quality (condition and extensiveness) } \\
\text { of ports on a scale from } 1 \text { (worst in } \\
\text { the world) to } 7 \text { (among the best in the } \\
\text { world), ln transformed values }\end{array}$ & WEF \\
\hline $\operatorname{LnRals}_{i t}$ & $\begin{array}{l}\text { Quality (condition and extensiveness) } \\
\text { of railroads on a scale from } 1 \text { (worst } \\
\text { in the world) to } 7 \text { (among the best in } \\
\text { the world), ln transformed values }\end{array}$ & WEF \\
\hline $\operatorname{LnLogis}_{i t}$ & $\begin{array}{l}\text { Ranking Logistics Performance } \\
\text { Index (LPI) per country based } \\
\text { on six dimensions (i.e., customs, } \\
\text { infrastructure, international } \\
\text { shipments, competence, tracking and } \\
\text { tracing, and timeliness) on a scale } \\
\text { from } 1 \text { (worst performer) to } 5 \text { (best } \\
\text { performer), ln transformed values }\end{array}$ & WB \\
\hline
\end{tabular}

(Interactive data available at https://tcdata360.worldbank.org/) 


\section{REFERENCES}

Amendolagine, V., Presbitero, A., Rabellotti, R., \& Sanfilippo, M. (2019). Local sourcing in Developing countries: The role of foreign direct investments and global value chains. World Development, 113(C), 73-88. doi:10.1016/j.worlddev.2018.08.010

Arbués, P., Baños, J., \& Mayor, M. (2015). The spatial productivity of transportation infrastructure. Transportation Research Part A, 75, 166-177. doi:10.1016/j.tra.2015.03.010

Aritua, B. (2019). The rail freight challenge for emerging economies: How to regain modal share. Washington, DC: World Bank. doi:10.1596/978-1-4648-1381-8

Arvis, J., Mustra, M., Ojala, L., Shepherd, B., \& Saslavsky, D. (2010). Connecting to compete: Trade logistics in the global economy, World Bank. doi:10.1596/24599

Arvis, J., Mustra, M., Panzer, J., Ojala, L., \& Naula, T. (2007). Connecting to compete: Trade logistics in the global economy, World Bank. doi:10.1596/24600

Arvis, J., Ojala, L., Wiederer, C., Shepherd, B., Raj, A., \& Kiiski, T. (2018). Connecting to compete: Trade logistics in the global economy, World Bank. doi:10.1596/29971

Balassa, B. (1978). Exports and economic growth: Further evidence. Journal of Development Economics, 5(2), 181-189. doi:10.1016/0304-3878(78)90006-8

Baltagi, B. (2016). Econometric analysis of panel data (5th ed). Chicchester: John Wiley \& Sons. ISBN-10: 0470518863.

Behar, A., Manners, P., \& Nelson, B. (2013). Exports and international logistics. Oxford Bulletin of Economics and Statistics, 75(6), 855-886. doi:10.1111/j.1468-0084.2012.00715.x

Bruinsma, F., Nijkamp, P., \& Rietveld, P. (1989). Employment impacts of infrastructure investments: A case study for the Netherlands. In K. Peschel (Ed.), Infrastructure and the space-economy (pp. 209-226). Berlin: Springer. doi:10.1007/978-3-642-75571-2_13

Button, K. (2008). Air transportation infrastructure in developing countries: Privatization and deregulation. Retrieved from

https://www.researchgate.net/publication/252202873_Air_transportation_infrastructure_ in_developing_countries_Privatization_and_deregulation

Button, K., Doh, S., \& Yuan, J. (2010). The role of small airports in economic development. Journal of Airport Management, 4(2), 125-136. ISSN: 1750-1938

Button, K., \& Yuan, J. (2013). airport transport and economic development: An examination of causality. Urban Studies, 50(2), 329-340. doi:10.1177/0042098012446999

Capineri, C., Leinbach, T., \& Gips, D. (2006). Freight transport, seamlessness, advantage in the global economy. European Journal of Transport and Infrastructure Research, 6(1), 23-38. doi:10.18757/ejtr.2006.6.1.4321

Carballo, J., Schaur, G., \& Volpe, C. (2017). Transportation and trade interactions: A trade facilitation perspective. In B. A. Blonigen, \& W. W. Wilson (Eds.), Handbook of International trade and transportation (pp. 422-450). Elgar Publishing.

Carter, E., Chadda, H., \& Schonfeld, P. (1984). A comparison of transportation planning in developed and developing countries. Transportation Quarterly, 38(1), 69-86. doi:10.1061/ (ASCE)UP.1943-5444.0000091

Celbis, M., Nijkamp, P., \& Poot, J. (2014). Infrastructure and trade: A meta-analysis. Region, 1 (1), 25-65. doi:10.18335/region.v1i1.25

Cho, H. (2014). Determinants and effects of logistics costs in container ports: The transaction cost economics perspective. The Asian Journal of Shipping and Logistics, 30(2), 193-215. doi:10.1016/j.ajsl.2014.09.004

Cosar, K., \& Demir, B. (2016). Domestic road infrastructure and international trade: Evidence from Turkey. Journal of Development Economics, 118, 232-244.

doi:10.1016/j.jdeveco.2015.10.001 
Donaldson, D. (2018). Railroads of the Raj: Estimating the impact of transportation infrastructure. American Economic Review, 108(4-5), 899-934. doi:10.1257/aer.20101199

Fink, C. (2002). Transport services: Reducing barriers to trade. Global economic prospects and the developing countries (pp. 97-127). International Bank for Reconstruction and Development/ The World Bank. ISBN 0-8213-4996-1

Florida, R., Mellander, C., \& Holgersson, T. (2015). Up in the air: The role of airports for regional economic development. The Annals of Regional Science, 54(1), 197-214. doi:10.1007/s00168-014-0651-z

Gabriele, A. (2006). Exports of services, exports of goods and economic growth in developing countries. Journal of Economics Integration, 21(2), 294-317. doi:10.11130/jei.2006.21.2.294

Garcia-Escribano, M., Góes, C. \& Karpowicz, I. (2015). Filling the gap: Infrastructure investment in Brazil. International Monetary Fund. IMF Working Paper No. 15/180. Retrieved from https://www.imf.org/en/Publications/WP/Issues/2016/12/31/Filling-theGap-Infrastructure-Investment-in-Brazil-43139

Giles, J., \& Williams, C. (2000). Export-led growth: A survey of the empirical literature and some non-causality results, Part 1. Journal of International Trade and Economic Development, 9, 261-337. doi:10.1080/09638190050086177

Hausman, W., Lee, H., \& Subramanian, U. (2013). The impact of logistics performance on trade. Production and Operations Management, 22(2), 236-252. doi:10.1111/j.1937-5956.2011.01312.x

Hesse, H. (2008). Export diversification and economic growth. Commission on growth and development. Working Paper No. 21. Retrieved from http://hdl.handle.net/10986/28040

Hoekman, B., \& Nicita, A. (2010). Assessing the Doha Round: Market access, transactions costs and aid for trade facilitation. The Journal of International Trade \& Economic Development, 19(1), 65-79. doi:10.1080/096381909033274

Hummels, D. (2007). Transportation costs and international trade in the second era of globalization. Journal of Economic Perspectives, 21(3), 131-154. doi:10/1257/jep.21.3.131

Jung, W., \& Marshall, P. (1985). Exports, growth and causality in developing countries. Journal of Development Economics, 18, 1-12. doi:10.1016/0304-3878(85)90002-1

Kodongo, O., \& Ojah, K. (2016). Does infrastructure really explain economic growth in SubSaharan Africa? Review of Development Finance, 6, 105-125. doi:10.1016/j.rdf.2016.12.001

Korinek, J., \& Sourdin, P. (2011). To what extent are high-quality logistics services trade facilitating? OECD Trade Policy Working Paper No. 108. OECD Publishing. doi: $10.1787 / 18166873$

Kunaka, C., Mustra, M., \& Saez, S. (2013). Trade dimensions of logistics services: A proposal for trade agreements. The World Bank Policy Research Working Paper. Retrieved from https://openknowledge.worldbank.org/handle/10986/12155

Kuznets, S. (1959). Six lectures on economic growth. Routledge.

Lakshmanan, T. (2007). The wider economic benefits of transportation: An overview. International transport forum, OECD [Discussion Paper]. doi:10.1787/20708270

Levin, A., \& Raut, L. (1997). Complementarities between exports and human capital in economic growth: Evidence from the semi-industrialized countries. Economic Development and Cultural Change, 46(1), 155-174. doi:10.1086/452325

Martí, L., Puertas, R., \& García, L. (2014a). The importance of the logistics performance index in international trade. Applied Economics, 46(24), 2982-2992. doi:10.1080/00036846.2014.916394

Martí, L., Puertas, R., \& García, L. (2014b). Relevance of trade facilitation in emerging countries' exports. The Journal of International Trade \& Economic Development, 23(2), 202-222. doi:10.1080/09638199.2012.698639 
Melo, P., Graham, D., \& Brage-Ardao, R. (2013). The productivity of transport infrastructure investment: A meta-analysis of empirical evidence. Regional Science and Urban Economics, 43, 695-706. doi:10.1016/j.regsciurbeco.2013.05.002

Munemo, J., Bandyopadhyay, S., \& Basistha, A. (2006). Chapter 21 Foreign aid and export performance: A panel data analysis of developing countries. In S. Lahiri (Ed.), Theory and practice of foreign aid (Frontiers of economics and globalization, vol. 1) (pp. 421-433). Bingley: Emerald Group Publishing Limited. doi:10.1016/S1574-8715(06)01021-9

Munim, Z. \& Schramm, H. (2018). The impacts of port infrastructure and logistic performance on economic growth: the mediating role of seaborne trade. Journal of Shipping Trade, 3(1). doi:10.1186/s41072-018-0027-0

Nordås, H. (2010). Time as a trade barrier. In D. Waters (Ed.), Global Logistics: New directions in supply chain management, 6th edition (pp. 347-364). London: Kogan Page.

Organisation and Economic Co-Operation for Development. International Transport Forum. (2013). Understanding the value of transport infrastructure 2013 [Task Force Report]. Retrieved from https://www.itf-oecd.org/sites/default/files/docs/13value.pdf

Organisation and Economic Co-Operation for Development. International Transport Forum (2016). Capacity to grow [Policy Paper]. Retrieved from https://www.oecd-ilibrary.org/ transport/international-transport-forum-policy-papers_24108871

Organisation and Economic Co-Operation for Development. (2018). Enhancing connectivity through transport infrastructure: The role of official development finance and private investment. The Development Dimension. Paris: OECD Publishing. doi:10.1787/9789264304505-en

Portugal-Pérez, A., \& Wilson, J. (2010). Export performance and trade facilitation reform: Hard and soft infrastructure. The World Bank Policy Research Working Paper 5261. doi:10.1596/1813-9450-5261

Ram, R. (1987). Exports and economic growth in developing countries: Evidence from time-series and cross-section data. Economic Development and Cultural Change, 36(1), 51-72. doi:10.1086/451636

Razali, N., \& Wah, Y. (2011). Power comparisons of Shapiro-Wilk, Kolmogorov-Smirnov, Lilliefors and Anderson-Darling tests. Journal of Statistical Modeling and Analytics, 2(1), 21-33. Retrieved from https://www.nrc.gov/docs/ML1714/ML17143A100.pdf

Rehman, F., Noman, A., \& Ding. Y. (2020). Does infrastructure increase exports and reduce trade deficit? Evidence from selected South Asian countries using a new Global Infrastructure Index. Journal of Economic Structures, 9(10). doi:10.1186/s40008-020-0183-X

Rodrigue, J-P., \& Notteboom, T. (2017). Transportation, economy and society. In J.-P. Rodrigue, C. Comtois, \& B. Slack (Eds.), The geography of transport systems (pp. 94-126). New York: Routledge.

Romer, P. (1994). The origins of endogenous growth. Journal of Economic Perspectives, 8(1), 3-22. doi: 10.1257/jep.8.1.3

Schwab, K. (2018). World Economic Form: The global competitiveness report 2017-2018 [Insight Report]. Retrieved from http://www3.weforum.org/docs/GCR2017-2018/ 05FullReport/TheGlobalCompetitivenessReport2017\%E2\%80\%932018.pdf

Schwab, K. (2018). World Economic Forum: The global competitiveness report 2018 [Insight Report]. Retrieved from http://www3.weforum.org/docs/GCR2018/05FullReport/ TheGlobalCompetitivenessReport2018.pdf

Shapiro, S. \& Wilk, M. (1965). An analysis of variance test for normality. Biometrika, 52(3/4), 591-611. doi:10.2307/2333709

Solow, R. (1956). A contribution to the theory of economic growth. The Quarterly Journal of Economics, 70(1), 65-94. doi.org/10.2307/1884513 
Suárez-Alemán, A., Morales, J., Serebrisky, T., \& Trujillo, L. (2016). When it comes to container port efficiency, are all developing regions equal? Transportation Research Part A: Policy and Practice, 86, 56-77. doi.org/10.1016/j.tra.2016.01.018

Subasat, T. (2002). Does export promotion increase economic growth? Some cross-section evidence. Development Policy Review, 20(3), 333-349. doi:10.1111/1467-7679.00175

Tahir, M., \& Azid, T. (2015). The relationship between international trade openness and economic growth in the developing economies: Some new dimensions. Journal of Chinese Economic and Foreign Trade Studies, 8(2), 123-139. doi:10.1108/JCEFTS-02-2015-0004

United Nations Conference on Trade and Development. (2006). Negotiations on transport and logistics: Issues to consider. Retrieved from https://unctad.org/system/files/officialdocument/sdtetlb20053_en.pdf

United Nations Conference on Trade and Development. (2018). Review of maritime transport. ISSN 0566-7682. Retrieved from https://unctad.org/system/files/official-document/ rmt2018_en.pdf

United Nations - Department of Economic and Social Affairs (2019). World economic situation and prospects for 1999 [Joint Report]. Retrieved from https://www.un.org/development/desa/dpad/document_gem/global-economicmonitoring-unit/world-economic-situation-and-prospects-wesp-report/

Upreti, P. (2015). Factors affecting economic growth in developing countries. Major Themes in Economics, 17, 37-54. Retrieved from https://scholarworks.uni.edu/mtie/vol17/iss 1/5/

Wang, C., Lim, M., Zhang, X., Zhao, L., \& Lee, P. (2020). Railway and road infrastructure in the Belt and Road Initiative countries: Estimating the impact of transport infrastructure on economic growth. Transportation Research Part A: Policy and Practice, 134, 288-307. doi:10.1016/j.tra.2020.02.009

Wang, M., \& Choi, C. (2018). How logistics performance promote the international trade volume? A comparative analysis of developing and developed countries. International Journal of Logistics Economics and Globalisation, 7(1), 49. doi:10.1504/IJLEG.2018.090504

Were, M. (2015). Differential effects of trade on economic growth and investment: A cross country empirical investigation. Journal of African Trade, 2, 71-85. doi:10.1016/j.joat.2015.08.002

Wilkins, A. (2018). To lag or not to lag? Re-evaluating the use of lagged dependent variables in regression analysis. Political Science Research and Methods, 6(2), 393-411. doi:10.1017/psrm.2017.4 